\title{
Experience with the use of olaparib in patients with ovarian cancer
}

\author{
Dolores Gallardo-Rincón, ${ }^{1,2 *}$ Gabriela Alamilla-García, ${ }^{1,2}$ Edgar Montes-Servín, ${ }^{2}$ Flavia Morales-Vázquez, ${ }^{1}$ \\ Claudia Cano-Blanco, ${ }^{1}$ Jaime Coronel-Martínez, ${ }^{1}$ Antonio Bahena-González, ${ }^{1,2}$ Raquel Gerson-Cwilich, ${ }^{4}$ \\ David Isla-Ortiz, ${ }^{3}$ Alfredo Toledo-Leyva, ${ }^{2}$ Elizabeth Montes-Servín, ${ }^{2}$ David Michel-Tello ${ }^{2}$ and
} Raquel Espinosa-Romero ${ }^{1,2}$

${ }^{1}$ Department of Medical Oncology; ${ }^{2}$ Ovarian Cancer Program; ${ }^{3}$ Department of Oncological Gynecology. Instituto Nacional de Cancerología; ${ }^{4}$ Department of Medical Oncology, Cancer Center, Centro Médico ABC. Mexico City, Mexico

\begin{abstract}
Introduction: More than the twenty percent of ovarian cancers are hereditary, and most have BRCA mutations. The $30 \%$ of Mexican patients with the BRCA1 mutation have the BRCA1 gene exon 9-12del deletion founder mutation (BRCA1 ex9-12del). BR$C A$-mutated tumors are more sensitive to PARP inhibitors such as olaparib. Objective: To show the clinical experience on the use of olaparib at Instituto Nacional de Cancerología in Mexico. Method: Ovarian cancer patients treated with olaparib from November 2016 to December 2018 were studied, and their characteristics, clinical response, progression-free survival (PFS) and toxicities were described. Results: Nineteen patients were assessed, with BRCA1 mutation being found in $78.9 \%$, out of which $21.1 \%$ were carriers of the ex9-12del founder mutation. The median of PFS was 12 months; for patients treated on second and third line it was greater than 15 months, and for those treated with a fourth and subsequent line it was 8.3 months. Patients with the founder mutation had better results. Toxicities were like those reported in previous studies. Conclusions: Olaparib offers greater PFS benefit as maintenance therapy after a first and second relapse. Patients with founder mutation have had sustained PFS.
\end{abstract}

KEY WORDS: BRCA mutation. Ovarian cancer. PARP inhibitor. BRCA1 founder mutation. Olaparib.

\section{Experiencia con el uso de olaparib en pacientes con cáncer de ovario}

\section{Resumen}

Introducción: Más del $20 \%$ de los cánceres de ovario puede ser hereditario y la mayoría tiene mutaciones BRCA. El 33 \% de las pacientes mexicanas con mutación BRCA1 tiene la mutación fundadora deleción del exón 9-12del del gen BRCA1 (BRCA1 ex9-12del). Los tumores BRCA mutados son más sensibles a inhibidores PARP como olaparib. Objetivo: Mostrar la experiencia clínica del uso de olaparib en el Instituto Nacional de Cancerología de México. Método: Se estudiaron las pacientes con cáncer de ovario tratadas con olaparib de noviembre de 2016 a diciembre de 2018 y se describieron sus características, respuesta clínica, supervivencia libre de progresión y toxicidades. Resultados: Se evaluaron 19 pacientes, 78.9 \% presentó mutación BRCA1, del cual 21.1 \% era portador de la mutación fundadora ex9-12del. La mediana de supervivencia libre de progresión global fue de 12 meses, para las pacientes tratadas tratadas con olaparib de mantenimiento posterior a segunda y tercera línea fue de > 15 meses y para las de cuarta línea o más fue de 8.3 meses. Las pacientes con mutación fundadora presentaron mejores respuestas. Las toxicidades fueron similares a las de estudios con el uso de olaparib. Conclusiones: Olaparib ofrece mayor beneficio en supervivencia libre de progresión como tratamiento de mantenimiento después de la primera y segunda recaída. Las pacientes con mutación fundadora han tenido respuesta sostenida.

PALABRAS CLAVE: Mutación BRCA. Cáncer de ovario. Inhibidor PARP. Mutación fundadora de BRCA1. Olaparib.

\footnotetext{
Correspondence:

Date of reception: 29-08-2019

*Dolores Gallardo-Rincón

Date of acceptance: 03-09-2019

E-mail: dgallardorincon@gmail.com

DOI: 10.24875/GMM.M20000361

Gac Med Mex. 2019;155:541-545

Contents available at PubMed

www.gacetamedicademexico.com license (http://creativecommons.org/licenses/by-nc-nd/4.0/).
} 


\section{Introduction}

Ovarian cancer is the type of gynecological cancer with the highest mortality. Worldwide annual incidence estimated for 2018 was 295,414 new cases, with 184,799 deaths, which corresponded to $63 \%$. Conversely, breast cancer had an incidence higher than 2 million new cases, with a mortality of $30 \%$, while the incidence of cervical cancer was 569,847 new cases, with a mortality of $55 \%$. In Mexico, the estimated incidence for ovarian cancer in 2018 was 4759 cases and 2765 deaths (58\%). ${ }^{1}$

More than $20 \%$ of ovarian cancers can be hereditary, ${ }^{2}$ and in 10 to $15 \%$ of Caucasian women they are associated with germline mutations in the BRCA genes. The prevalence of mutations in BRCA1/2 is high in patients of Hispanic origin; a study reported a prevalence of $28 \%$, with 65 to $70 \%$ of mutations corresponding to BRCA1 and from 30 to $35 \%$ to $B R C A 2$. In addition, $33 \%$ of BRCA mutations corresponded to the BRCA1 ex9-12del founder mutation. ${ }^{3}$

BRCA genes are involved in the process of deoxyribonucleic acid (DNA) double-strand breaks repair by homologous recombination. Neoplastic cells with mutations in BRCA genes have a limited capacity to repair DNA damage, but despite this they continue to be viable and survive using alternate repair pathways. There is a family of proteins called PARP (poly-ADP ribose polymerase) that includes the PARP-1, PARP-2 and PARP-3 enzymes, which are necessary in the repair of single-stranded DNA ruptures.

One study showed that tumors with mutations in BRCA were especially sensitive to PARP inhibitors, since mutation in the BRCA1 gene induces increased levels of a transcription factor called ETS1, which under hypomethylation conditions binds more avidly to the PARP1 gene promoter region, which increases its expression. The PARP1 enzyme is involved in the heterologous repair route, which is produced by non-homologous DNA end joining, which makes it highly prone to errors. This repair pathway gives the malignant cell viability enough to continue with disease progression. ${ }^{4}$

Olaparib is a PARP inhibitor that, by preventing the repair of DNA single-stranded breaks, coupled with a deficiency in homologous recombination repair, causes cell death. ${ }^{5}$ It is indicated as maintenance treatment in patients with ovarian cancer with mutation in the BRCA genes who experience partial or complete response after platinum-based chemotherapy. ${ }^{6}$
Available clinical trials show that the use of olaparib as maintenance treatment offers benefits versus placebo in terms of progression-free survival (PFS) in patients with recurrent ovarian cancer. Study 19, a randomized, double blind phase 2 trial, showed that olaparib, after a first line of platinum-based chemotherapy, offers significant benefits in PFS versus placebo to patients with high-grade serous carcinoma (8.4 versus 4.8 months, hazard ratio $=0.35,95 \% \mathrm{Cl}=0.25$ $0.49, p<0.0001)$, especially in those with mutated BRCA (11.2 versus 4.3 months, hazard ratio $=0.18,95$ $\% \mathrm{Cl}=0.10-0.31, \mathrm{p}<0.0001) .{ }^{7}$ Subsequently, SOLO-2, a randomized phase 3 trial, confirmed Study 19 results by showing a significant PFS increase (19.1 versus 5.5 months, hazard ratio $=0.30,95 \% \mathrm{Cl}=0.22-0.41$, $p<0.0001)$ in patients with recurrent ovarian cancer sensitive to platinum with mutation in BRCA1/2 treated with olaparib. ${ }^{8}$ Furthermore, maintenance treatment with olaparib has been associated with a long-lasting response, longer than two years. ${ }^{9}$

This work presents the clinical experience with the use of olaparib in women with ovarian cancer with mutations in BRCA at the National Cancer Institute of Mexico

\section{Method}

Ovarian cancer patients were selected by genetic evaluation for the detection of mutations in $B R C A 1 / 2$, from November 2016 to December 2018. A peripheral blood sample of each patient was analyzed by second-generation sequencing. Large rearrangements, such as BRCA1 ex9-12del, were assessed using the multiple ligation-dependent amplification test (Quest Diagnostics). Clinical characteristics including age, the proportion of patients with breast and ovarian cancer, clinical stage at diagnosis and ovarian cancer histological subtypes were recorded. All patients signed the informed consent letter to be included in the study.

Chemotherapy treatment lines prior to olaparib and their response were recorded. Patients were treated with $800 \mathrm{mg} /$ day as maintenance therapy after complete or partial response to chemotherapy. According to grade 3 toxicities, an adjustment was made to half the dose (400 mg/day). During olaparib treatment, platinum-sensibility status, previous treatment lines, PFS and dose adjustment due to olaparib treatment-related toxicity were recorded.

Survival analysis was carried out using the Kaplan-Meier method, and between-group differences 


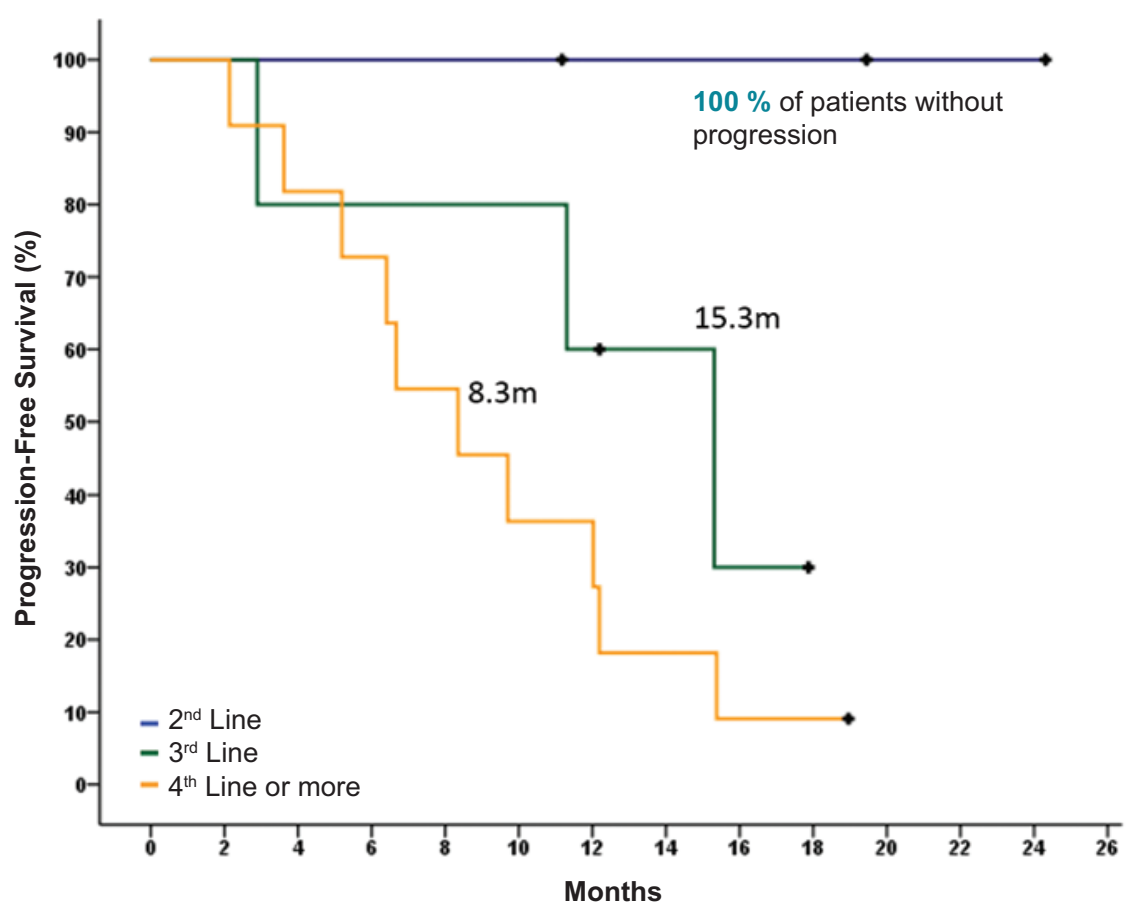

Figure 1. Progression-free survival of patients treated with olaparib according to previous treatment line.

(second line versus third line, fourth line or more) were determined with the log-rank test or Breslow's test, with a $p$-value $<0.05$ being regarded as significant. All analyses were carried out with the SPSS software, version 23 (SPSS, Inc., Chicago, IL, USA).

\section{Results}

The present study included 19 patients with ovarian cancer, with a median age of 51 years (range 40 to 67 years); $21.1 \%$ had a diagnosis of double primary breast and ovarian cancer. At diagnosis, $10.5 \%$ of patients had clinical stage I cancer, $5.3 \%$ had stage IIB, $10.5 \%$ stage IIIB, $57.9 \%$ stage IIIC and $15.8 \%$ stage IV.

High grade serous histological subtype was observed in $78.9 \%$, endometrioid subtype in $10.5 \%$ and adenocarcinoma without the subtype being determined in $10.5 \% ; 78.9 \%$ of the population had mutations in BRCA1 and $21.1 \%$ in BRCA2; four patients $(21.1 \%)$ had the BRCA1 ex9-12del founding mutation.

Treatment combinations prior to olaparib included carboplatin plus paclitaxel or gemcitabine in $52.6 \%$ of patients, cisplatin plus paclitaxel or gemcitabine in $36.8 \%$ of cases and carboplatin plus paclitaxel plus bevacizumab in $10.5 \%$ The result of previous treatment with olaparib was complete response in $42.1 \%$, partial response in $52.6 \%$ and stable disease in $5.3 \% ; 47.4 \%$ of patients were partially sensitive to platinum (platinum-free interval of six to 12 months) and $52.6 \%$ were sensitive to platinum (platinum-free interval > 12 months).

Olaparib was administered as maintenance treatment in $15.8 \%$ of patients after the second line of treatment (after the first relapse), in $26.3 \%$, subsequent to third line and in $57.9 \%$, after the fourth or more lines. Until December 2018, $36.9 \%$ of patients continued to receive olaparib. The four patients with the BRCA1 ex9-12del founding mutation continued with response to maintenance treatment with olaparib.

Patient median overall PFS was 12 months (95\% $\mathrm{Cl}=8.74-15.31)$. Patients treated with olaparib after a second line of treatment showed no progression after 16 months of treatment, while median PFS for patients treated with olaparib after a third line was 15.3 months (95\% Cl $=9.0-21.5)$, and 8.3 months $(95 \% \mathrm{Cl}=4.5$ 11.8 ) for those treated with olaparib as fourth or subsequent lines, with a tendency to a significant difference in PFS between both latter groups of patients $(p=0.056)$ (Fig. 1).

Olaparib treatment was associated with hematological and non-hematological toxicities, which in most cases were grade 1 , and in $47.4 \%(9 / 19)$, dose 
Table 1. Toxicities associated with olaparib treatment

\begin{tabular}{|c|c|c|c|c|c|c|}
\hline \multirow[t]{2}{*}{ Characteristic } & \multicolumn{2}{|c|}{ Grade 1} & \multicolumn{2}{|c|}{ Grade 2} & \multicolumn{2}{|c|}{ Grade 3} \\
\hline & $\%$ & $\mathbf{n}$ & $\%$ & n & $\%$ & n \\
\hline \multicolumn{7}{|l|}{ Hematological toxicity } \\
\hline Anemia* & 21.1 & $4 / 19$ & 26.3 & $5 / 19$ & 10.5 & $2 / 19$ \\
\hline Neutropenia & 5.3 & $1 / 19$ & 21.1 & $4 / 19$ & - & - \\
\hline Thrombocytopenia & 10.5 & $2 / 19$ & - & - & - & \\
\hline Leukopenia & 26.3 & $5 / 19$ & 21.1 & $4 / 19$ & - & \\
\hline Lymphopenia & 26.3 & $5 / 19$ & - & - & 16.7 & $3 / 19$ \\
\hline \multicolumn{7}{|c|}{ Non-hematological toxicity } \\
\hline Nausea & 52.6 & $10 / 19$ & 15.8 & $3 / 19$ & - & - \\
\hline Fatigue & 68.4 & $13 / 19$ & 31.6 & $6 / 19$ & - & - \\
\hline Headache & 47.4 & $9 / 19$ & - & - & - & - \\
\hline Abdominal pain & 52.6 & $10 / 19$ & 15.8 & $3 / 19$ & - & - \\
\hline Pneumonitis ${ }^{\star \star}$ & - & - & - & - & 5.2 & $1 / 19$ \\
\hline
\end{tabular}

reduction was required. The main hematological toxicity was anemia, which affected $58 \%$ of patients, out of which $37 \%$ had grade 2 or 3 anemia, with a $50 \%$ dose adjustment being required in three of the eight patients who had received four or more lines of treatment. Other less frequent hematological toxicities were neutropenia, thrombocytopenia, leukopenia and lymphopenia. Nausea was the main toxicity among non-hematological toxicities, which affected $68 \%$ of patients, $53 \%$ with grade 1 . Other toxicities included fatigue, headache, abdominal pain and pneumonitis. Among grade 1 toxicities, a higher proportion of non-hematological adverse reactions was observed, while among grade 2 and 3 toxicities, there was a higher proportion of hematological adverse reactions (Table 1).

\section{Discussion}

The cohort study carried out with patients treated with olaparib at the National Cancer Institute shows a median PFS benefit of 12 months, similar to the 11.2 months observed in Study 19 for the group of patients with BRCA mutation. ${ }^{7}$ The highest PFS benefit was observed in patients treated with olaparib as maintenance therapy after the first and the second relapse (> 15 months), in comparison with the group treated after three or more relapses (8.3 months)

Previous studies have not documented differences in therapeutic response between patients with BRCA1 and BRCA2 mutations; ${ }^{7,8}$ however, our research showed better results in all four patients with $B R C A 1$ ex9-12del founding mutation, with a PFS of up to 18.9 months. These four patients accounted for $21.1 \%$ of the subjects with the BRCA1 mutation.

Toxicity data were similar to those observed in the SOLO2 trial, with a higher incidence of anemia in our study, which was associated with larger number of previous chemotherapy lines..$^{8,10}$ On the other hand, there was one patient with pneumonitis who had been diagnosed with breast cancer 15 years prior and who was treated with previous radiotherapy, which could have favored this side effect with synergy to the use of olaparib.

\section{Conclusions}

The number of previous therapy lines is a prognostic factor that is crucial for the response to olaparib as maintenance therapy, which translates into a better PFS. Data from previous studies with olaparib and our results in a patient population with recurrent, sensitive ovarian cancer seem to indicate that the best scenario for maintenance treatment with olaparib is after second and third therapy line in comparison with patients who have received four or more previous lines.

Olaparib dose reduction in patients with hematological or gastrointestinal toxicity suggests that it has no negative impact on PFS.

Toxicity was associated with a larger number of previous chemotherapy lines. There is a tendency to a sustained PFS for maintenance therapy with olaparib in patients with a founding mutation, and this is the first time such finding is reported.

Our results support the use of olaparib as maintenance treatment in patients with recurrent, platinum-sensitive ovarian cancer, ideally after the first and second relapse.

\section{Conflict of interests}

Dolores Gallardo Rincón and Gabriela Alamilla García have participated as speakers for AstraZeneca. Dolores Gallardo Rincón has also participated as lecturer with Roche and Lilly. The other authors have no conflicts of interest to declare.

\section{References}

1. Ferlay J, Ervik M, Lam F, Colombet M, Mery L, Piñeros M, et al. Global cancer observatory: cancer today. Francia: International Agency for Research on Cancer; 2018.

2. Toss A, Tomasello C, Razzaboni E, Contu G, Grandi G, Cagnacci A, et al. Hereditary ovarian cancer: not only BRCA 1 and 2 genes. Biomed Res Int. 2015;2015:341723. 
3. Villarreal-Garza C, Álvarez-Gómez RM, Pérez-Plasencia C, Herrera LA, Herzog J, Castillo D, et al. Significant clinical impact of recurrent BRCA1 and BRCA2 mutations in Mexico. Cancer. 2015;121:372-378.

4. Li D, Bi FF, Cao JM, Cao C, Li CY, Liu B, et al. Poly (ADP-ribose) polymerase 1 transcriptional regulation: a novel crosstalk between histone modification $\mathrm{H} 3 \mathrm{~K} 9 \mathrm{ac}$ and $\mathrm{ETS} 1$ motif hypomethylation in BRCA1-mutated ovarian cancer. Oncotarget. 2014;5:291-297.

5. Buisson R, Dion-Côté AM, Coulombe $Y$, Launay H, Cai H, Stasiak AZ, et al. Cooperation of breast cancer proteins PALB2 and piccolo BRCA2 in stimulating homologous recombination. Nat Struct Mol Biol. 2010;17:1247-1254

6. FDA approved olaparib (LYNPARZA, AstraZeneca Pharmaceuticals LP) for the maintenance treatment of adult patients with deleterious or suspected deleterious germline or somatic BRCA-mutated (gBRCAm or sBRCAm) advanced epithelial ovarian, fallopian tube or primary peritoneal cancer who are in complete or partial response to first-line platinum-based [Sitio web. EE. UU.: Food and Drug Administration; 2018.
7. Ledermann J, Harter P, Gourley C, Friedlander M, Vergote I, Rustin G, et al. Olaparib maintenance therapy in patients with platinum-sensitive relapsed serous ovarian cancer: a preplanned retrospective analysis of outcomes by BRCA status in a randomised phase 2 trial. Lancet Oncol. 2014:15:852-861.

8. Pujade-Lauraine E, Ledermann JA, Selle F, Gebski V, Penson RT, Oza AM, et al. Olaparib tablets as maintenance therapy in patients with platinum-sensitive, relapsed ovarian cancer and a BRCA1/2 mutation (SOLO2/ENGOT-Ov21): a double-blind, randomised, placebo-controlled, phase 3 trial. Lancet Oncol. 2017;18:1274-1284.

9. Lheureux S, Lai Z, Dougherty BA, Runswick S, Hodgson DR, Timms KM, et al. Long-term responders on olaparib maintenance in high-grade serous ovarian cancer: clinical and molecular characterization. Clin Cance Res. 2017;23:4086-4094.

10. Moore K, Colombo N, Scambia G, Kim B-G, Oaknin A, Friedlander M, et al. Maintenance olaparib in patients with newly diagnosed advanced ovarian cancer. N Engl J Med. 2018;379:2495-2505. 